\title{
Antiglobulin sera: comparison between serological tests and immunoelectrophoresis
}

\author{
G. C. JENKINS ${ }^{1}$ \\ From the Medical Research Council Experimental Haematology Research Unit, \\ Wright-Fleming Institute of Microbiology, St. Mary's Hospital Medical School, London
}

SYNOPSIS Reactions of selected antiglobulin sera with sensitized cells are related to their precipitation patterns with normal serum on immunoelectrophoresis. The components which react with adsorbed complement are anti- $\beta_{1}$ and further evidence of this is obtained by the effect of the addition of human serum components on the antiglobulin reactions with 'complement-coated' cells.

The findings are discussed in the light of recent work by various authors.

Red cells which have been incubated with fresh serum containing a complement-binding blood group antibody can be agglutinated best by serum which contains anti-'non- $\gamma$ ' globulin components (Mollison and Cutbush, 1955; Cutbush, Crawford, and Mollison, 1955). It was demonstrated by Dacie, Crookston, and Christenson (1957) that the anti-'non- $\gamma$ ' globulin was in fact detecting complement on the sensitized red cells and not the antibody.

Peetoom, van der Hart, and van Loghem (1960) and Jenkins, Polley, and Mollison (1960) indicated that the essential antiglobulin components in this type of reaction were anti- $\beta_{1}$. In the course of subsequent work further observations were made which provided additional evidence that 'complement-coated' cells were agglutinated by anti- $\beta_{1}$ components of the anti-'non- $\gamma$ ' globulins. These observations are contained in the present paper.

\section{METHODS}

IMMUNOELECTROPHORESIS Several samples of fresh human serum were electrophoresed on the same agar block. Antiglobulin sera were placed in intervening gutters and precipitation allowed to take place at room temperature. After 48 hours the preparations were washed, stained, dried, and photographed.

PREPARATION OF SERUM FRACTIONS Human serum was separated by zone electrophoresis in a starch block after the method described by Kunkel (1954). The block was divided into $1.0 \mathrm{~cm}$. or $0.5 \mathrm{~cm}$. segments and each fraction eluted into saline. The protein content of the

${ }^{1}$ Present address: The Clinical Laboratories, The London Hospital, E.1. Received for publication 20 August 1962. eluates was determined by a modification of the FolinCiocalteau micro method (Kunkel and Tiselius, 1951) and identified against whole fresh serum by means of paper micro-electrophoresis (Kohn, 1958).

THE ANTIGLOBULIN SERA Of the antiglobulin sera examined, 12 reagents were selected for the present series. All were produced in rabbits except for S.70 and P. 4, for which goats were used.

The immunizing material was in most cases whole human serum. Hypogammaglobulinaemic serum was used to produce anti-Pi and a preparation of $\gamma$ globulin for the production of S.80, S.132, and S.146 were prepared by injecting a complex of potato-anti-potato protein which had been allowed to adsorb human complement (Ellis and Gell, 1958).

SENSITIZED CELLS The antiglobulin sera were tested against red cells, which had been moderately strongly sensitized by an incomplete $\mathrm{Rh}$ antibody, against cells sensitized by normal incomplete cold antibody (anti-H), and against cells sensitized by anti-Lea .

$\mathrm{Rh}$ antibody never seems to bind complement whereas the normal incomplete cold antibody essentially binds complement. In order to ensure that complement was adsorbed onto the Lewis-sensitized cells, the red cells were first treated with the serum containing antibody (heated to $56^{\circ} \mathrm{C}$. for 30 minutes) then washed and exposed to fresh serum.

PREPARATION OF 19s globulins The 'heavy' component was obtained from human plasma by subjecting it to ultra-centrifugation three times after a preliminary separation with ethyl ether.

In accordance with previous observers (MüllerEberhard, Kunkel, and Franklin, 1956; Wallenius, Trautman, Kunkel, and Franklin, 1957), this sample of $19 S$ globulins was found to consist of only $a_{2}$ and $\beta_{2}\left(\gamma_{1}\right)$ globulins on paper electrophoresis. 


\section{RESULTS}

COMPARISON OF ANTIGLOBULIN REAGENTS The reactions of the antiglobulin sera with cells sensitized with $\mathrm{Rh}$ antibody and normal incomplete cold antibody are shown in Table I. On the basis of their reactions it is possible to divide the reagents broadly into those which react with both types of sensitized cells and those which react with the normal incomplete cold sensitized cells, but not at all or only slightly with Rh-sensitized cells (S.6, anti-Pi, S.132, and S.55/84). No antisera reacted exclusively with $\mathrm{Rh}$-sensitized cells though some (such as S.80) reacted with these cells much more strongly than with normal incomplete cold-sensitized cells.

The reactions with sensitized cells are in some measure reflected in the pattern of precipitation produced by immunoelectrophoresis (Fig. 1). It will be observed that those sera which react with both types of sensitized cells have lines in the $\gamma$ region and also an abundance of lines in the $\alpha$ and $\beta$ areas (R.35, Q.C.19/1, P.29, S.70).

S.6 is a notable example of an antiglobulin serum which does not react at all with $\mathrm{Rh}$-sensitized cells. Its precipitation pattern shows no $\gamma$ line and no albumin line. The remaining lines consist of $\alpha_{1}, \alpha_{2}, \beta_{1}$, and a fainter $\beta_{2}$ line on the extreme right. This configuration is reproduced by serum $55 / 84$. In this case the antibody which was revealed by the very weak reaction with $\mathbf{R}$-sensitized cells was presumably not sufficiently strong to produce a precipitation line in the $\gamma$ area.

Anti-Pi, though similar to $\mathrm{S} .6$ in its reactions with the sensitized cells, differs from it in lacking a $\beta_{2}$ line and producing an albumin line. Once again the $\gamma$ line is absent.

Important reactions are those displayed by reagents S.132 and S.146 which were produced in a rabbit against human complement. It will be seen that $\mathbf{S} .132$ strongly agglutinates cells sensitized with normal incomplete cold antibody and produces two lines only on immunoelectrophoresis, both of which appear to lie in the $\beta$ region. Despite the weak reactions with $R$ h-sensitized cells there is no line in the pattern produced by S.132, but in the sample later obtained from the same animal (S.146), a welldeveloped $\gamma$ line appears which agrees with the much stronger agglutination of Rh-sensitized cells; however, the reaction with 'complement-coated' cells remains unchanged.

In general there is a good relationship between the presence or absence of a $\gamma$ line on immunoelectrophoresis and the ability of the reagents to react with $\mathbf{R h}$-sensitized cells. Furthermore some quantitative correlation is apparent; that is to say, where excess of antibody is indicated by a wellmarked prozone, the $\gamma$ globulin precipitation line is correspondingly strong (S.80, Q.C.19/1, R.35). A

TABLE I

REACTIONS OF ANTIGLOBULIN SERA WITH CELLS SENSITIZED WITH A NON-COMPLEMENT-BINDING ANTIBODY (ANTI-D) AND WITH A COMPI.EMENT-BINDING ANTIBODY (ANTI-H)

\begin{tabular}{|c|c|c|c|c|c|c|c|c|c|c|c|}
\hline \multicolumn{2}{|c|}{ Antiglobulin ${ }^{1}$} & \multirow{2}{*}{$\begin{array}{l}2 \\
+1 \\
++\end{array}$} & \multirow{2}{*}{$\frac{4}{+}+t$} & \multirow{2}{*}{$\frac{8}{+}+$} & \multirow{2}{*}{ 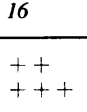 } & \multirow{2}{*}{ 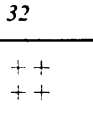 } & \multirow{2}{*}{$\frac{64}{++}+$} & \multirow{2}{*}{$\frac{128}{(++)}$} & \multirow{2}{*}{$\frac{256}{++}$} & \multirow{2}{*}{$\frac{512}{++}$} & \multirow{2}{*}{$\frac{1,024}{t+}$} \\
\hline R.35 & $\begin{array}{l}\text { Anti-D } \\
\text { Anti-H }\end{array}$ & & & & & & & & & & \\
\hline P.29 & $\begin{array}{l}\text { Anti-D } \\
\text { Anit-H }\end{array}$ & $\overline{+}+$ & + & $\begin{array}{l}+ \\
++\end{array}$ & $\begin{array}{l}++ \\
++\end{array}$ & $\begin{array}{l}+++ \\
++\end{array}$ & $\begin{array}{l}++ \\
+\end{array}$ & $\begin{array}{l}++ \\
+\end{array}$ & ++ & + & + \\
\hline Q.C.19/1 & $\begin{array}{l}\text { Anti-D } \\
\text { Anti-H }\end{array}$ & $\overline{+}$ & $\begin{array}{l}+ \\
+\end{array}$ & $\begin{array}{l}++ \\
++\end{array}$ & $\begin{array}{l}++ \\
++\end{array}$ & $\begin{array}{l}t+t \\
+t\end{array}$ & $\begin{array}{l}++t \\
+\end{array}$ & $\begin{array}{l}+1 \\
+\end{array}$ & ++ & $+t$ & + \\
\hline P.4 & $\begin{array}{l}\text { Anti-D } \\
\text { Anti-H }\end{array}$ & $\begin{array}{l}+ \\
++\end{array}$ & $\begin{array}{l}+ \\
+\end{array}$ & $\begin{array}{l}+t \\
+\end{array}$ & $\begin{array}{l}++ \\
+\end{array}$ & $\begin{array}{l}++ \\
+\end{array}$ & $\begin{array}{l}++ \\
+\end{array}$ & $\begin{array}{l}+1 \\
+\end{array}$ & ++ & ++ & + \\
\hline S. 70 & $\begin{array}{l}\text { Anti-D } \\
\text { Anti-H }\end{array}$ & $\begin{array}{l}(+) \\
++\end{array}$ & $\begin{array}{l}+ \\
++\end{array}$ & $\begin{array}{l}+ \\
+\end{array}$ & $\begin{array}{l}+ \\
+\end{array}$ & $\begin{array}{l}++ \\
+\end{array}$ & $\begin{array}{l}++ \\
(+)\end{array}$ & $\begin{array}{l}++ \\
(+)\end{array}$ & ++ & ++ & ++ \\
\hline S.80 & $\begin{array}{l}\text { Anti-D } \\
\text { Anti-H }\end{array}$ & $\begin{array}{l}(+) \\
+\end{array}$ & $\begin{array}{l}(+) \\
+\end{array}$ & $\begin{array}{l}+ \\
+\end{array}$ & $\begin{array}{l}+ \\
T\end{array}$ & $\begin{array}{l}++ \\
(+)\end{array}$ & $\frac{+}{-}$ & $\begin{array}{l}+ \\
-\end{array}$ & ++ & ++ & --+ \\
\hline Anti-Pi & $\begin{array}{l}\text { Anti-D } \\
\text { Anti-H }\end{array}$ & $\bar{t}+$ & $\bar{t}+$ & $\bar{t}+$ & $\bar{t}+$ & - & $\overline{(+)}$ & $\overline{(+)}$ & - & - & - \\
\hline S. 6 & $\begin{array}{l}\text { Anti-D } \\
\text { Anti-H }\end{array}$ & $\overline{(+)}$ & $\frac{-}{+}$ & $\overline{+}$ & $\bar{t}+$ & $\bar{t}+$ & $\bar{t}+$ & $\bar{t}+$ & - & - & - \\
\hline S.55/84 & $\begin{array}{c}\text { Anti-D } \\
\text { Anti-H }\end{array}$ & $\overline{+}$ & $\overline{+}$ & + & + & $\begin{array}{l}(+) \\
+\end{array}$ & $\begin{array}{c}(+) \\
+\end{array}$ & + & - & - & - \\
\hline S.85 & $\begin{array}{c}\text { Anti-D } \\
\text { Anti-H }\end{array}$ & $\begin{array}{l}+ \\
+\end{array}$ & $\begin{array}{l}+ \\
+\end{array}$ & $\begin{array}{l}+ \\
+t\end{array}$ & $\begin{array}{l}(+) \\
++\end{array}$ & $\bar{t}+$ & + & $\overline{+}$ & - & - & - \\
\hline S. 132 & $\begin{array}{c}\text { Anti-D } \\
\text { Anti-H }\end{array}$ & + & $\overline{+}$ & -+ & $\begin{array}{l}(+) \\
++\end{array}$ & $\begin{array}{l}+ \\
+\end{array}$ & + & $\begin{array}{l}(+) \\
+\end{array}$ & $(+)$ & - & - \\
\hline S. 146 & $\begin{array}{c}\text { Anti-D } \\
\text { Anti-H }\end{array}$ & $\begin{array}{l}+ \\
+\end{array}$ & $\begin{array}{l}+ \\
++\end{array}$ & $\begin{array}{l}++ \\
++\end{array}$ & $\begin{array}{l}+++ \\
++\end{array}$ & $\frac{++}{+}$ & $\begin{array}{l}+t+ \\
+\end{array}$ & $\begin{array}{l}+\div \\
+\end{array}$ & $+\div$ & + & + \\
\hline
\end{tabular}

${ }^{1}$ The dilutions of antiglobulin serum are expressed as reciprocals. 


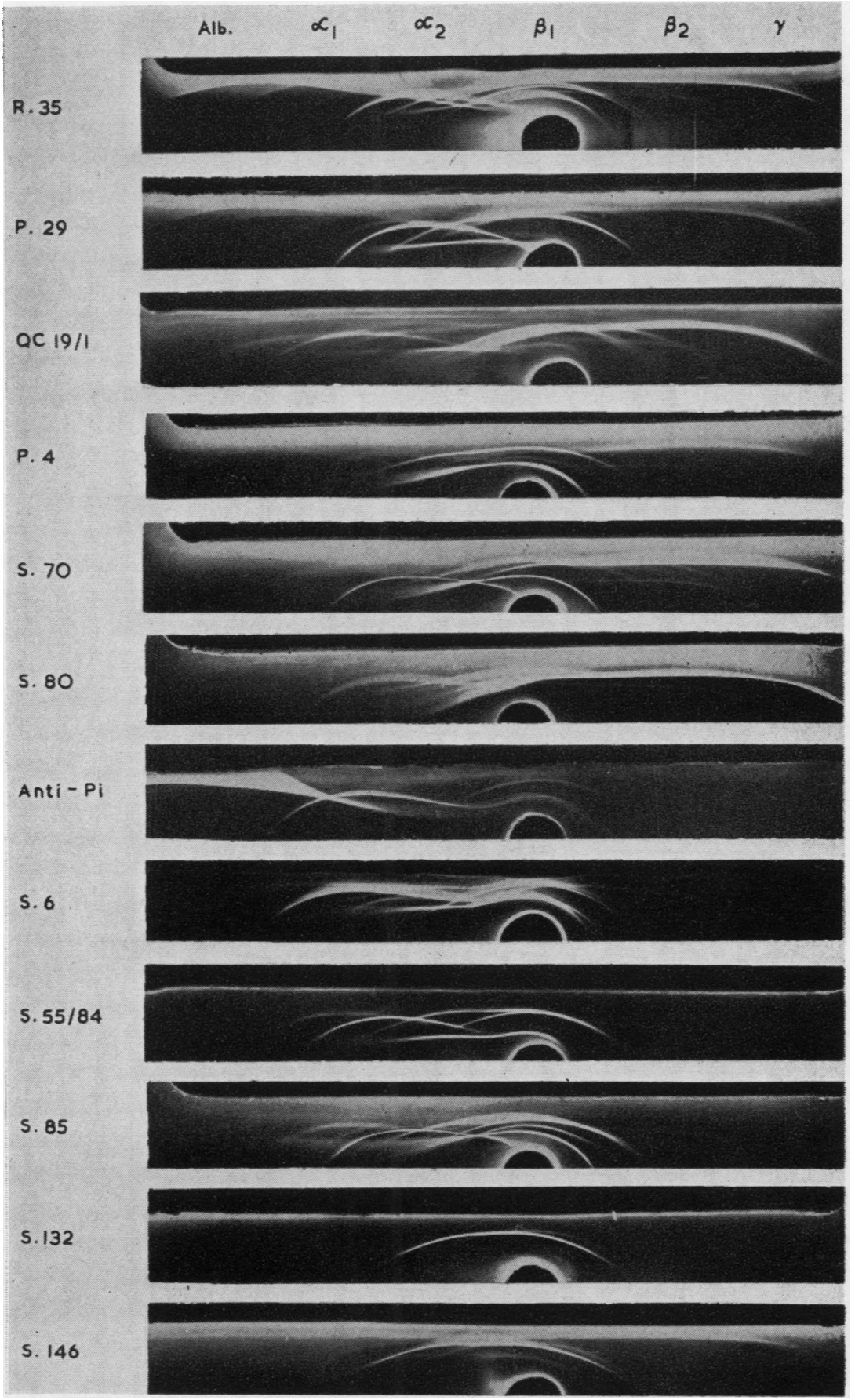

FIG. 1. Immunoelectrophoretic patterns produced by the antiglobulin sera with normal serum. 
quantitative relationship is less striking in the reactions with normal incomplete cold-sensitized cells but some sera (S.6, S.55/84, and S.132) which show high titre antibody against these cells in the antiglobulin reaction, even to the extent of showing a prozone, also have prominent lines in the $\beta$ region.

IDENTIFICATION OF AN ANTI-COMPLEMENT COMPONENT BY INHIBITION WITH SERUM PROTEIN COMPONENTS In order to try to identify the essential antiglobulin component concerned in anti-complement reactions, fractions of human serum obtained by zone electrophoresis were each used to neutralize an antiglobulin reagent which was then tested for its ability to agglutinate sensitized cells.

An equal volume of each 'neutralizing' solution in a concentration of $0.5 \mathrm{mg}$. protein per millilitre was added to the antiglobulin reagent and the mixtures left for $\mathbf{1 0}$ minutes at room temperature.

The antiglobulin serum treated with each fraction was then tested with cells sensitized with anti-Lea, normal incomplete cold antibody, and also incomplete anti-D.

Fractions obtained from normal human serum (G.J.) The results are shown in graph form in Figure 2.

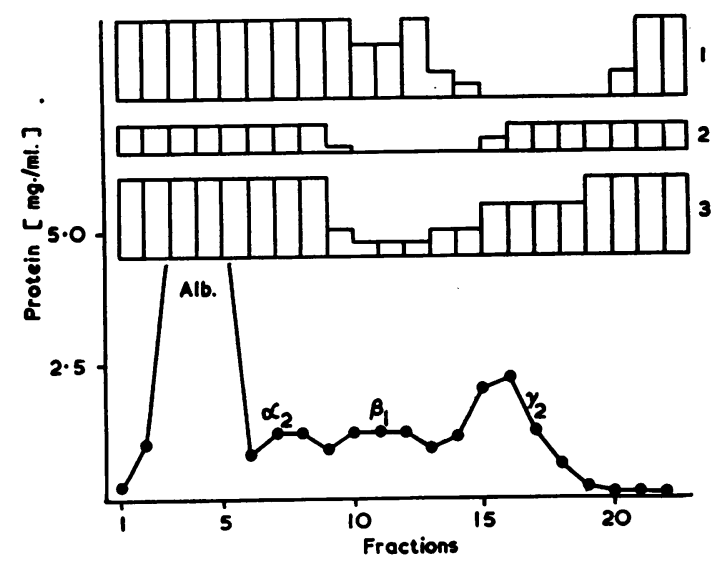

FIG. 2. Effect on antiglobulin reactions of adding to the antiglobulin serum 22 different fractions of normal human serum (G.J.) prepared by a starch-block electrophoresis. A sample of each fraction, after elution from the starch block, was tested by paper electrophoresis and the mobility of the different fractions is indicated in the figure; the protein concentration of each fraction is also shown.

The antiglobulin test was carried out with red cells sensitized with three different blood group antibodies: (1) anti-D: (2) the normal incomplete cold antibody; and (3) anti-Le ; in (2) and (3) the red cells were exposed to fresh serum to provide an opportunity for the adsorption of complement.

The stren?th of the antiglobulin reaction is indicated by the height of the blocks (arbitrary scale).

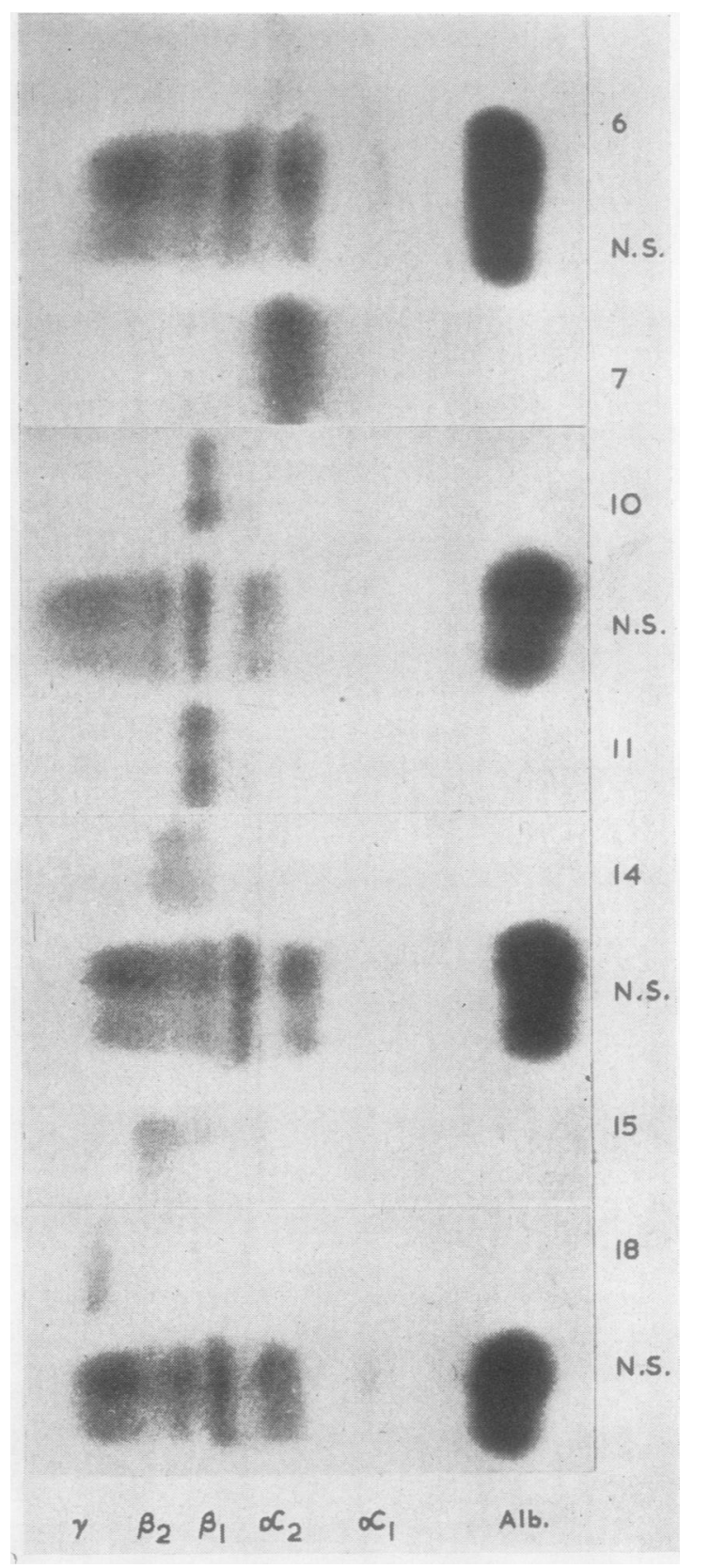

FIG. 3. Paper electrophoresis ( $p \mathrm{H}$ 8.6) of selected fractions of normal serum (G.J.) used for antiglobulin inhibition. Each globulin fraction is identified by its mobility compared with the components of whole serum (N.S.). 


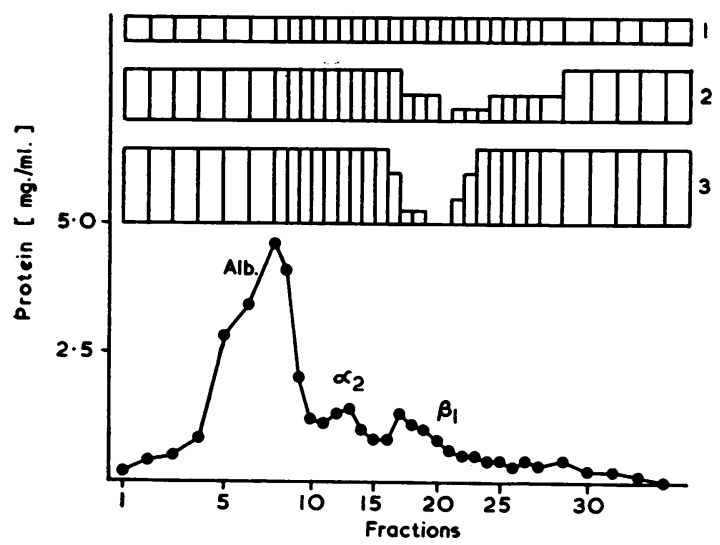

FIG. 4. As Fig. 1 except that the serum (G.P.) submitted to starch-block electrophoresis was obtained from a donor with hypogammaglobulinaemia and that the starch block was cut into a greater number of segments before elution.

FIG. 5. Paper electrophoresis of selected fractions of hypogammaglobulinaemic serum (G.P.) used for antiglobulin inhibition compared with whole serum (N.S.).

FIG. 4

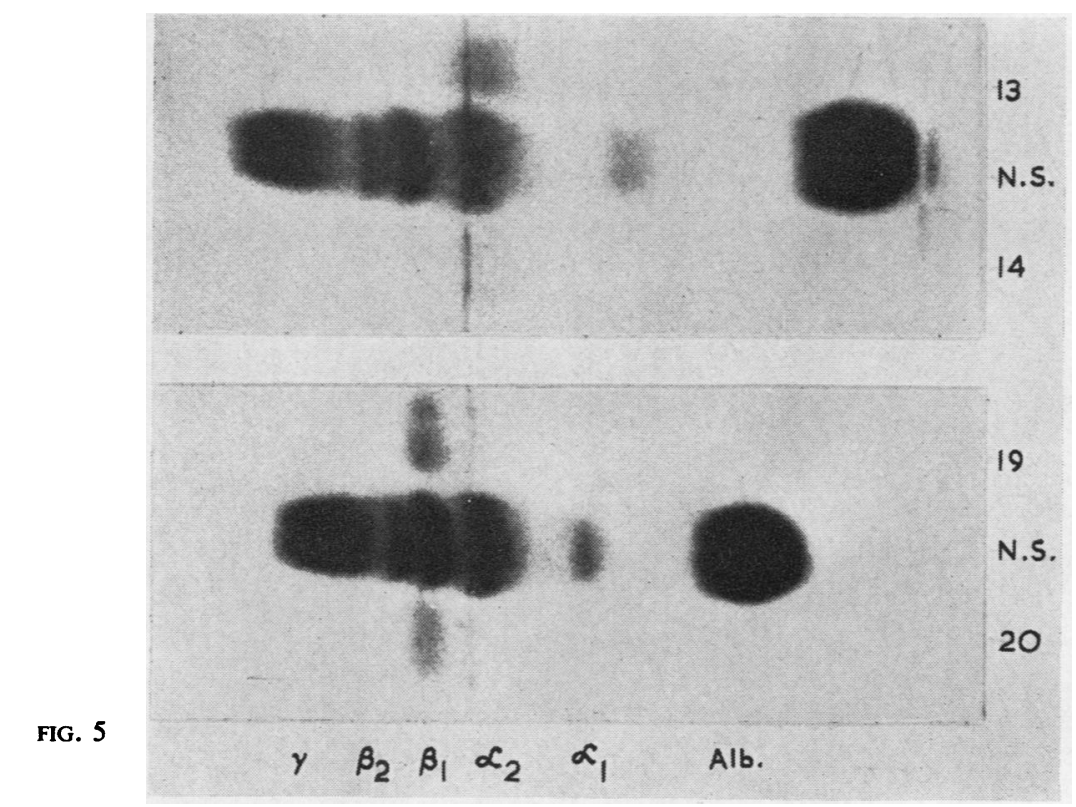

As was expected, the agglutination of Rh-sensitized cells was inhibited by fractions 15 to 20 which move in the slow $\gamma$ positions (Fig. 3). The minimal reduction in activity produced by fraction 10 may be explained by the fact that small amounts of $\gamma$ globulin may display fast mobilities extending as far as the $a_{2}$ region.

The reactions with 'complement-coated' cells were maximally inhibited by fractions in a different region (10-12) which contained predominantly $\beta_{1}$ globulin. With $L^{\mathrm{a}}$-sensitized cells the antiglobulin reactions were inhibited to a less degree by fractions obtained from the $\gamma$ region also (fractions 17 and 18).

Fractions obtained from hypogammaglobulinaemic serum The serum (G.P.) contained only $25 \mathrm{mg}$. of $\gamma$ globulin per $100 \mathrm{ml}$. The starch block in which it was separated was divided into $0.5 \mathrm{~cm}$. segments in order to obtain preparations of the individual globulins as pure as possible. Saline eluates of the fractions were again used at a concentration of 0.5 mg. of protein per millilitre for neutralization of the antiglobulin reagent which was then tested against cells sensitized with the same antibody-containing sera as before.

It will be seen (Fig. 4) that the reaction with Rhsensitized cells was not affected by any fraction. This observation confirms that no effective quantity of $\gamma$ globulin was present. Furthermore it helps to establish that the inhibition of this antibody reaction by protein from the 'non- $y$ ' area in the experiment using 


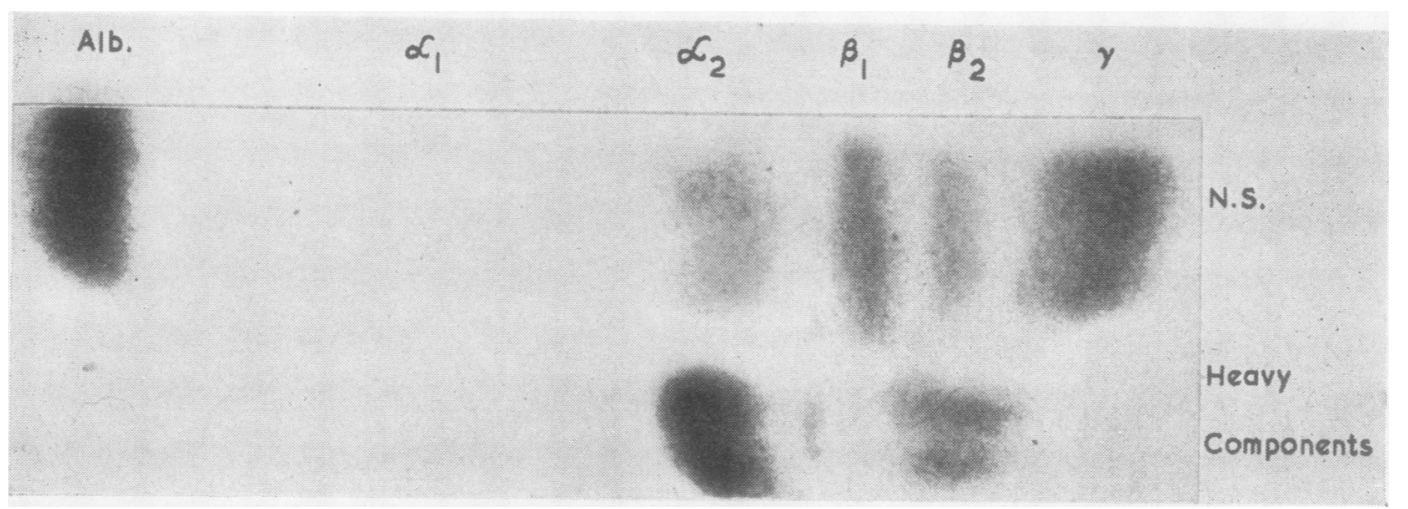

FIG. 6. Paper electrophoresis of $19 S$ components (heavy component) compared with whole serum (N.S.).

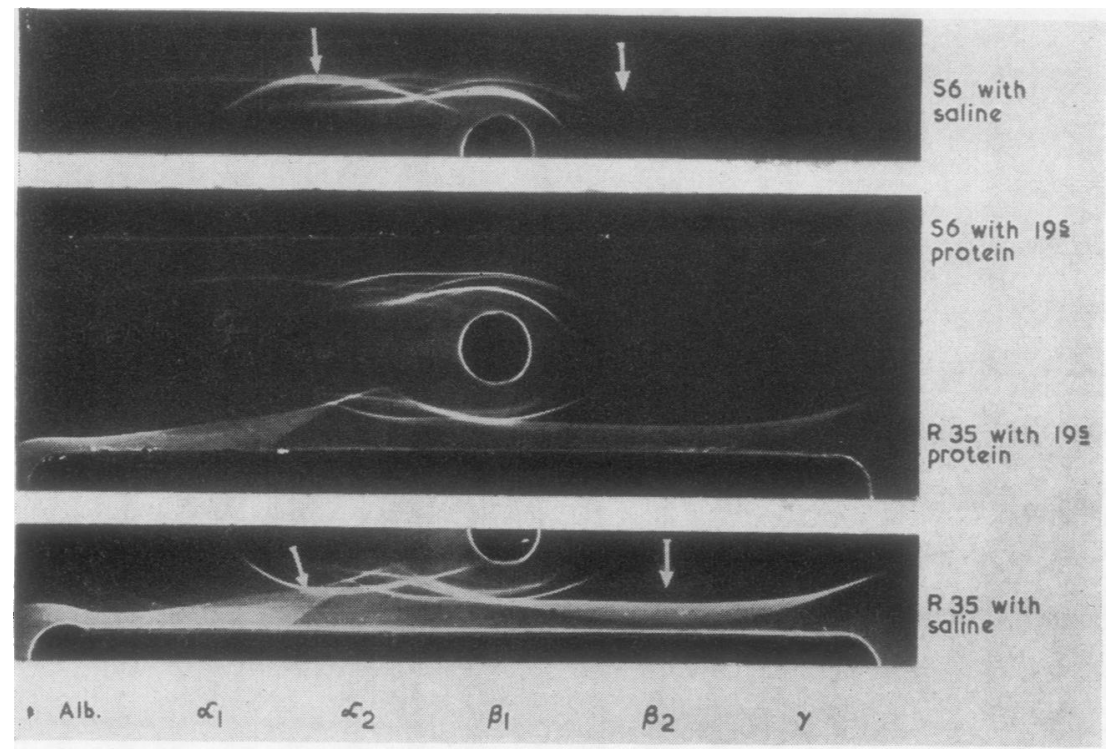

FIG. 7. Immunoelectrophoretic patterns produced by two of the antiglobulin sera (S.6 and $R .35$ ) with normal serum showing the effect of absorption with $19 S$ globulin components.

whole serum components was due to a small $\gamma$ globulin component with a comparatively fast mobility.

The reactions with both of the complement-binding antibodies were maximally inhibited by a fraction (fraction 20) which is again identified as pure $\beta_{1}$ globulin (Fig. 5). The zone of inhibition in the reactions with Lewis-sensitized cells was well confined to the fractions containing $\beta_{1}$ globulin. The inhibition of reactions with normal incomplete cold-sensitized cells was prolonged into the $\beta_{2}$ region.

ADDITION OF $19 s$ GLOBULINS TO ANTIGLOBULIN SERUM The addition of an equal volume of $19 S$ protein
(Fig. 6) in a concentration of $1 \mathrm{mg}$. per millilitre to an $\stackrel{\sim}{\circ}$ antiglobulin serum produced no inhibition of its $N$ reactions with cells sensitized with $R h$ or normal incomplete cold antibodies.

When the 'neutralized' antiglobulin reagent was investigated by immunoelectrophoresis it was shown that, in agreement with the tests with sensitized cells, $\stackrel{\infty}{\stackrel{\oplus}{+}}$ the $\gamma$ line was retained as were also the two lines which have been demonstrated to be associated with anti-complement activity. The $\alpha_{2}$ and $\beta_{2}$ lines were $\mathbb{D}$ lost (Fig. 7). It is unlikely therefore that either anti- $\alpha_{2} \stackrel{ᄋ}{\mathbb{D}}$ or anti- $\beta_{2} M$ are concerned in the agglutination of $\varrho$ 'complement-coated' cells. 


\section{DISCUSSION}

The immunoelectrophoretic patterns produced by this series of antiglobulin reagents agree with the well-accepted fact that anti-non- $\gamma$ globulin components react with 'complement-coated' cells. The result obtained with serum S.132 in particular agrees with the suggestion that the essential components for reaction with bound complement are anti- $\beta_{1}$. Matuhasi and Usui (1958) also used a reagent prepared by immunizing a rabbit with adsorbed human complement and it appeared that lines were predominantly in the $\beta_{1}$ area on immunoelectrophoresis.

Additional evidence of the anti- $\beta_{1}$ nature of the anti-complement component is provided here by the results obtained from the inhibition of antiglobulin serum by components of human serum. The inhibition of reactions with 'complement-coated' Lewissensitized cells by some fractions of $\gamma$ globulin was possibly due to slight contamination with $\beta_{1}$ components. It has been recorded, however, that a reaction between the Lewis antibody protein itself and an anti- $\beta_{2} \mathrm{M}$ component in the antiglobulin serum sometimes occurs, where the anti- $\beta_{2} M$ globulin is strong enough (Mollison, 1961, p. 241). If such a reaction were contributing to the agglutination in this experiment it is possible that some of the inhibition by faster moving $\gamma$ globulin components was due to the presence of $\beta_{2} \mathrm{M}$ globulin. It is significant therefore that when the antiglobulin serum (R.35) which had been used was tested with Lewis-sensitized cells without the addition of complement a weak agglutination was obtained.

On the other hand, it is shown that in the similar experiment using serum fractions from a case of hypogammaglobulinaemia inhibition of the antiglobulin reactions with 'complement-coated' Lewissensitized cells is confined to only a few fractions containing $\beta_{1}$ globulin. It seems possible therefore that serum G.P. lacks $\beta_{2}$ M globulin as well as being deficient in the main $\gamma$ globulin component. This is also suggested by the fact that anti-Pi, which was raised against serum G.P., lacks a $\beta_{2} \mathrm{M}$ line on immunoelectrophoresis (see Fig. 1) and furthermore was found not to agglutinate Lewis-sensitized cells unless they were first exposed to complement.

Ellis and Gell (1958) reported that the major portion of antibodies to complement was directed against a $\beta$ globulin. Using an anti-complement serum identical to that produced by Professor Gell (S.132 in the present work), Müller-Eberhard and Nilsson (1960) have demonstrated that the main anti-complement component is directed against $\beta_{1}$. They showed that this component of $\beta$ globulin was partially taken up by antigen-antibody complexes which converted it to a faster moving component electrophoretically $\left(\beta_{1 \mathrm{a}}\right)$, an effect which was also produced by treatment with zymozan or by storage of the serum. They identified it as a hydrazinesensitive part of the third component of complement $\left(\mathrm{C}_{3}^{\prime} \mathrm{a}\right)$.

Various authors (Peetoom et al., 1960; Jenkins et al. 1960; Pondman, Rosenfield, Tallal, and Wasserman, 1960) have produced evidence that the $\beta_{1}$ globulin concerned in the anti-complement reaction is $\mathrm{C}^{\prime}{ }_{4}$. Müller-Eberhard and Nilsson (1960), however, pointed out that unlike $\mathrm{C}_{4}^{\prime}, \beta_{1 \mathrm{c}}$ precipitates with the euglobulin fraction of serum. It appears likely, therefore, that at least two anti- $\beta_{1}$ components are concerned in the anti-complement reaction each directed against different components of complement, that is to say one against $\mathbf{C}^{\prime}{ }_{3}$ a and the other against $C^{\prime}{ }_{4}$. It is not possible to say from these observations which of these two anti- $\beta_{1}$ components is the more important or indeed if both are essential for the detection of complement-binding blood group antibodies. It is possibly of some significance that an antiglobulin serum produced by animal injection of adsorbed complement (S.132), which produced a strong anti- ${ }^{\prime}{ }_{3}$ a component (Müller-Eberhard, 1961), agglutinated 'complement-coated' cells less strongly than a reagent such as R.35 which was obtained by injection of whole serum. That is to say, it is possible that the anti- $\mathrm{C}_{4}^{\prime}$ component of anti- $\beta_{1}$ is really the more important one where this type of anti-globulin reaction is concerned.

I wish to thank Professor P. G. H. Gell for a number of the rabbit antiglobulin sera and the Aberdeen Transfusion Centre for those obtained from goats. To Dr. R. A. Keckwick I am grateful for the ultracentrifuge preparations. I should like to thank Dr. P. L. Mollison for his invaluable advice and helpful criticism.

\section{REFERENCES}

Cutbush, Marie, Crawford, Hal, and Mollison, P. L. (1955). Brit. J. Haemat., 1, 410.

Dacie, J. V., Crookston, J. H., and Christenson, W. N. (1957). Ibid., 3 , 77.

Ellis, H. A., and Gell, P. G. H. (1958). Nature (Lond.), 181, 1667.

Jenkins, G. C., Polley, Margaret J., and Mollison, P. L. (1960). Ibid., 186, 482.

Kohn, J. (1958). Ibid., 181, 839.

Kunkel, H. G. (1954). Methods of Biochemical Analysis, vol. 1, p. 141. Interscience Publishers, N.Y.

- and Tiselius, A. (1951). J. gen. Physiol., 35, 89.

Matuhasi, T., and Usui, M. (1958). Med. Biol., 46, 258.

Mollison, P. L. (1961). Blood Transfusion in Clinical Medicine, 3rd ed. Blackwell, Oxford.

-

Müller-Eberhard, H. J. (1961). Acta Soc. Med. upsalien., 66, 152.

$\longrightarrow$, Kunkel, H. G., and Franklin, E. C. (1956). Proc. Soc. exp. Biol. (N.Y.), 93, 146.

- , and Nilsson, U. (1960). J. exp. med., 111, 217.

Peetoom, F., van der Hart, Mia, and van Loghem, J. J. Jr. (1960). Proc. VIIth Congr. europ. Soc. Haemat., London, 1959, Pt. 2, p. 1146.

Pondman, K. W., Rosenfield, R. E., Tallal, L., and Wasserman, L. R. (1960). Vox Sang. (Basel), n.s. 5, 297.

Wallenius, G., Trautman, R., Kunkel, H. G., and Franklin, E. C. (1957). J. biol. Chem., 225, 253. 